\title{
Analisis Kinerja Ekonomi Dan Pengelolaan Keuangan Daerah Provinsi Papua Barat
}

\author{
Rully Novie Wurarah, Siti Aisah Bauw \\ Dosen Fakultas Ekonomi dan Bisnis, Universitas Papua \\ Permalink/DOI: http://dx.doi.org/10.32830/jfres.v1i1.1032.g777
}

Received: May 2018; Accepted: August 2018; Published: September 2018

\begin{abstract}
Abstrak
Kesejahteraan masyarakat Papua Barat yang digambarkan dengan kondisi ekonomi makro masih sangat jauh dari harapan yang diinginkan. IPM Papua Barat sejak berdirinya Provinsi ini selalu berada pada rangking 2-3 paling bawah dari 32-34 provinsi. Jumlah penduduk miskin meskipun menurun setiap tahunnya namun masih diatas rata-rata nasional. Dilain pihak dana pembangunan yang sudah digunakan untuk membangun ekonomi di Papua Barat cukup besar. Dari gambaran tersebut perlu dipertanyakan apakah pengelolaan keuangan telah memberikan perubahan terhadap kinerja ekonomi Provinsi papua Barat? Kesimpulan penelitian: 1) Selama lima tahun terakhir pertumbuhan ekonomi mengalami perlambatan disebabkan ketergantungan perekonomian Papua Barat lebih didominasi oleh sektor migas, pertambangan yang selama kurun waktu tersebut mengalami penurunan output, 2) Indikator pembanguan tingkat pengangguran cenderung menurun dan berfluktuasi disebabkan oleh menurunnya jumlah eksport pada sektor sektor migas dan pertambangan sehingga mempengaruhi penyerapan tenaga kerja pada semua sektor dan terjadi peningkatan output pada sektor pertanian, konstruksi dan administrasi pemerintah serta jasa lainnnya, 3) Peningkatan alokasi belanja modal selama 5 tahun terakhir tidak konsisten dan lebih banyak dialokasikan untuk pengadaan mesin, bangunan dan tanah sehingga kurang memberikan dorongan terhadap penciptaan output pada sektor-sektor yang produktif, 4) Alokasi belanja terhadap sektor strategis pertanian hanya 3-4.6 persen dari alokasi belanja selama 5 tahun yang mengakibatkan pendapatan golongan menengah kebawah mengalami stagnan, 5) Efektifitas alokasi belanja kurang sinkron dengan tujuan yang dicapai karena alokasi belanja lebih didominasi oleh belanja administrasi pemerintah.
\end{abstract}

Kata Kunci : Kesejahteraan, kinerja ekonomi, alokasi belanja, efektifitas

\begin{abstract}
The welfare of the people of West Papua who are depicted by macroeconomic conditions are still very far from the desired expectations. West Papua's HDI since the establishment of the Province has always been ranked at the bottom 2-3 of 32-34 provinces. The number of poor people although decreasing every year is still above the national average. On the other hand the development funds that have been used to build the economy in West Papua are quite large. From this description it needs to be questioned whether financial management has changed the economic performance of West Papua Province? The conclusion are 1) West Papua is more dominated by the oil and gas sector, mining which during this period experienced a decline in output, 2) the number of exports in the oil and gas sector and mining sector affecting employment in all sectors 3) Increased allocation of capital expenditure over the past 5 years is inconsistent and less giving encouragement to the creation of output in productive sectors, 4) Allocation of expenditure to the agricultural strategic sector is only 3 to 4.6 percent of expenditure allocation which results in stagnant middle and lower income, 5) Effectiveness of expenditure allocation less synchronous because spending allocations are dominated by government administration spending.
\end{abstract}

Key words: Welfare, economic performance, expenditure allocation, effectiveness

How to Cite: Wurarah, R.N., Bauw, S.A. (2018). Analisis Kinerja Ekonomi dan Pengelolaan Keuangan Daerah Provinsi Papua Barat. JFRES: Journal of Fiscal and Regional Economy Studies, 1 (1), 95-108. doi: http://dx.doi.org/10.32830/jfres.v1i1.1032.g777 


\section{PENDAHULUAN}

Pembangunan ekonomi pada setiap daerah dituntut agar mengembangkan potensi-potensi ekonomi yang mampu menggerakkan perekonomian daerah melalui perencanaan pembangunan ekonomi yang rasional (efisien dan efektif) berdasarkan karakteristik daerah dan sektor unggulan serta mengarah kepada visi dan misi pembangunan di daerah yang termuat dalam Rencana Pembangunan Daerah. Melalui proses pembangunan ekonomi, sektor-sektor ekonomi memilik keterkaitan antara sektor yang satu dengan sektor lainnya. Secara makro untuk mengembangkan satu sektor ekonomi memerlukan input/masukan dari sektor lain. Untuk tujuan tersebut sangat diperlukan pemilihan alat analisis yang tepat dalam model ekonomi regional yang mampu mendeteksi sektor-sektor unggulan, tingkat penyerapan tenaga kerja sektoral dan tingkat pendapatan. Secara rasional, output dari suatu program pembangunan bisa menjadi input bagi program pembangunan yang lain.

Output yang dihasilkan dari suatu program pembangunan didasarkan atas pembiayaan yang termuat dalam program tersebut, karena dalam Peraturan Menteri Dalam Negeri Nomor 54 Tahun 2010 dinyarakan bahwa analisis pengelolaan keuangan daerah dimaksudkan untuk menghasilkan gambaran tentang kapasitas atau kemampuan keuangan daerah dalam mendanai penyelenggaraan pembangunan daerah. Analisis ini didasarkan atas informasi yang dapat mempengaruhi pertumbuhan pendapatan daerah seperti angka rata-rata pertumbuhan pendapatan daerah masa lalu, asumsi indikator makroekonomi, kebijakan intensifikasi dan ekstensifikasi pendapatan daerah serta kebijakan di bidang keuangan negara.

Penggunaan model makroekonomi regional dalam mekanisme perencanaan pembangunan ekonomi berawal dari analisis untuk mengetahui potensi ekonomi dan karekteristik sektoral dengan demikian diharapkan para perencana di daerah dapat mengetahui secara lebih mendalam mengenai sektor-sektor unggulan yang menguntungkan untuk dikembangkan baik dilihat dari sisi pertumbuhan, penyerapan tenaga kerja dan kontribusinya terhadap pendapatan daerah.
Adam Smith dalam Pressman (2002) menjelaskan bahwa aktivitas pemerintah yaitu melaksanakan kegiatan untuk mencegah monopoli, memberikan pertahanan dari ancaman luar negeri, memberikan ketertiban keamanan internal dan ketentuan pemerintah atas barang publik. Dalam perekonomian moderen Mangkusubroto (2008) menyatakan bahwa, peran pemerintah dapat digolongkan menjadi peran alokasi, distribusi dan stabilisasi, sebab menurut Stiglitz (1986) terjadinya kegagalan pasar dapat menimbulkan intervensi pemerintah melalui berbagai program kegiatan. Selanjutnya dikatakan bahwa terjadinya kegagalan tersebut karena: a) pemerintah tidak dapat mengantisipasi akibat kebijaksanaan yang diambilnya, b) pemerintah terbatas di dalam mengendalikan akibat kebijaksanaan, c) pemerintah di dalam membuat kebijaksanaan sering tidak memiliki kemampuan untuk melaksanakannya, d) pemerintah memberikan pelayanan pada kelompok tertentu atau kepentingan tertentu.

Kebijakan fiskal dapat dilakukan melalui pengaturan anggaran pengeluaran dan penerimaan pemerintah. Pada kondisi terjadi inflasi biasanya kebijakan fiskal akan berbentuk mengurangi pengeluaran pemerintah dan meningkatkan pajak. Sebaliknya apabila pengangguran serius maka pemerintah berusaha menambah pengeluaran dan berusaha mengurangi pajak. Kebijakan moneter dapat dilakukan dengan mempengaruhi jumlah uang beredar dan tingkat suku bunga. Sedangkan pada pengawasan langsung dapat dilakukan dengan membuat peraturan-peraturan.

Dalam perekonomian suatu daerah, peranan pemerintah dibutuhkan dalam menyediakan legal system atau peraturan-peraturan yang tidak dapat disediakan oleh sektor privat dan untuk mengantisipasi bila terjadi kegagalan pasar. Terjadinya kegagalan pasar disebabkan oleh kompetisi yang tidak sempurna, publik goods, eksternalitas dan kegagalan informasi. Pada kondisi kompetisi tidak sempurna menunjukkan bahwa di dalam pasar tidak sempurna dan cenderung monopoli, dicirikan oleh harga yang terjadi biasanya lebih tinggi dan jumlah produksi lebih sedikit Peran Pemerintah diharapkan dapat mengatur dan memperbaiki agar kesejahteraan masyarakat tidak terdepresiasi. Pada kondisi 
public goods yang memiliki karakteristik non exludable dan non rivalry, maka akan timbul fenomena free rider, artinya orang akan berlomba-lomba untuk tidak membayar dalam menikmati barang tersebut. Sistem penyediaan barang seperti ini tidak dapat dilakukan oleh sektor privat, sehingga menjadi kewajiban bagi pemerintah untuk menyediakannya.

Secara konseptuali, Peranan pemerintah umumnya mendistribusikan pendapatan dari yang kaya kepada yang miskin secara lebih adil dan bijaksana serta menyediakan merit goods. Musgrave (1959) menyebutkan merit goods adalah barang-barang yang seharusnya disediakan meskipun masyarakat tidak memintanya. Masyarakat sering tidak bijaksana atau tidak mempunyai pengetahuan yang cukup untuk mengalokasikan sumber ekonomi yang dimiliki. Peranan pemerintah terfokus pada memfasilitasi masyarakat untuk mengalokasikan kebutuhan masyarakat.

Secara umum fungsi pemerintah dalam perekonomian modern dapat dibagi menjadi: a) fungsi alokasi, dengan mengusahakan agar alokasi sumber-sumber ekonomi dilaksanakan secara efisien; b) fungsi distribusi, oleh Kaldor mengatakan bahwa suatu tindakan dikatakan bermanfaat apabila golongan yang memperoleh manfaat dari tindakan tersebut memberikan kompensasi bagi golongan yang mengalami kerugian sehingga posisi golongan yang rugi tetap sama seperti halnya sebelum adanya tindakan yang bersangkutan, c) fungsi stabilisasi, terhadap guncangan keadaan yang akan menimbulkan pengangguran dan inflasi yang harus ditangani melalui kebijakan moneter.

Pengeluaran pemerintah termasuk kedalam kebijakan fiskal bersama dengan pajak. Perubahan pengeluaran pemerintah ini akan mengubah ekuilibrium jangka pendek perekonomian. Perubahan fiskal akan memengaruhi pengeluaran yang direncanakan dan menggeser kurva IS dalam Model IS-LM. Pergeseran dalam kurva IS tersebut memengaruhi pendapatan nasional dan tingkat bunga, seperti dalam gambar 1 .

Kenaikan pengeluaran pemerintah sebesar $\Delta \mathrm{G}$ sebagai pengganda pengeluaran pemerintah dalam perpotongan Keynesian menyatakan bahwa pada tingkat bunga berapapun perubahan dalam kebijakan fiskal ini menaikkan pendapatan sebesar $\Delta \mathrm{G} /(1-\mathrm{MPC})$, sehingga kurva IS bergeser ke kanan sebesar jumlah ini. Ekuilibrium perekonomian bergerak dari titik A ke titik B, kenaikan pengeluaran pemerintah akan meningkatkan pendapatan dan bunga. Pengeluaran yang direncanakan akan naik ketika pemerintah meningkatkan belanjanya atas barang dan jasa. Kenaikan pengeluaran yang direncanakan ini akan mendorong produksi barang dan jasa, yang menyebabkan pendapatan total $\mathrm{Y}$ meningkat.

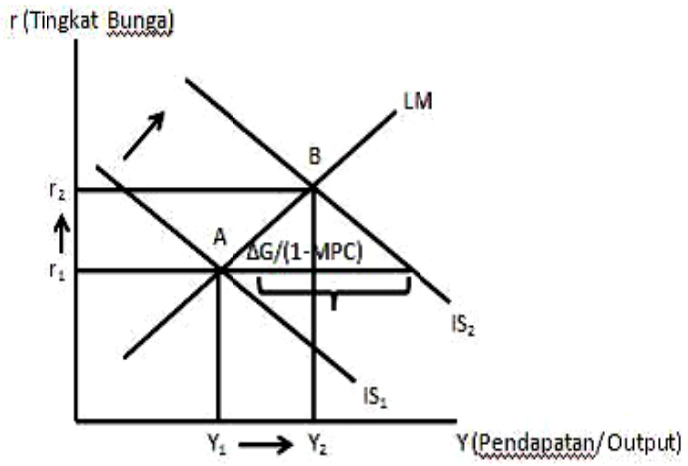

Gambar 1. Kurva IS-LM

Berdasarkan teori perkembangan pengeluaran pemerintah menunjukkan bahwa produk domestik bruto (PDB) akan mempengaruhi besarnya pengeluaran pemerintah dan sebaliknya pengeluaran pemerintah sebagai variabel independen, akan mempengaruhi produk domestik bruto (PDB). John Due (1968) sebelumnya telah mengemukakan bahwa pemerintah dapat mempengaruhi tingkat PDB nyata dengan mengubah persediaan berbagai faktor yang dapat dipakai dalam produksi melalui program-program pengeluaran pemerintah seperti pendidikan.

Kegiatan yang dilakukan pemerintah yang mendorong besaran jumlah pengeluaran negara mempunyai pengaruh terhadap perekonomian masyarakat. Hal tersebut sudah dibuktikan oleh Landau (1986) bahwa pengeluaran pemerintah di bidang militer dan pendidikan berkorelasi negative terhadap pertumbuhan ekonomi, sementara untuk pendidikan sendiri berkorelasi kuat dan investasi pemerintah berkorelasi positif walaupun tidak signifikan. Lin (1994) mengatakan bahwa pengeluaran pemerintah akan meningkatkan pertumbuhan ekonomi (PDB) dengan laju 
yang semakin mengecil. Pengeluaran pemerintah mencerminkan kebijakan pemerintah, sehingga apabila pemerintah telah menetapkan suatu kebijakan untuk membeli barang dan jasa, maka pengeluaran pemerintah tersebut mencerminkan biaya yang harus dikeluarkan untuk melaksanakan kebijakan tersebut.

Pelaksanaan pembangunan daerah merupakan program yang melibatkan segenap lapisan masyarakat, sedangkan pemerintah hanya sebagai katalisator dan fasilitator untuk menyediakan berbagai sarana dan fasilitas pendukung, termasuk anggaran belanja dalam rangka terlaksananya pembangunan tersebut. Pengeluaran tersebut sebagian digunakan untuk administrasi pembangunan dan segaian lain untuk kegiatan pembangunan. Alokasi belanja terhadap pelaksanaan pembangunan tersebut akan meningkatkan pengeluaran agregat sehingga mempertinggi tingkat kegiatan ekonomi. Meningkatnya kegiatan ekonomi, mengakibatkan aliran penerimaan pemerintah melalui PAD mengalami peningkatan.

Dalam hal alokasi belanja yang telah dilaksanakan oleh perangkat daerah di bidang ekonomi, pertanyaan yang muncul adalah seberapa besar kualitas pembelanjaan yang telah dilakukan telah berdampak pada peningkatan indikator pembangunan ekonomi?.Dengan demikian komposisi pembelanjaan menjadi sangat penting dan perlu diboboti untuk menganalisa seberapa besar dan kuatnya kualitas belanja terhadap capaian indikator ekonomi makro yang diinginkan.

\section{METODE PENELITIAN}

Penelitian ini menggunakan data sekunder yang diperoleh dari instansi terkait seperti BPS, Badan Pengelolaan Keuangan Daerah, Bappeda Provinsi Papua Barat kurun waktu 2012 sampai dengan 2016. Untuk mengukur kinerja ekonomi dan keuangan digunakan analisis deskriptif dan analisis input output.

\section{HASIL DAN PEMBAHASAN}

\section{Struktur PDRB dan Pertumbuhan Ekonomi Menurut Lapangan Usaha}

Struktur perekonomian Provinsi Papua Barat selama periode tahun 2010 hingga 2016 menunjukkan pergeseran kontribusi perekonomian. Pada tahun 2010 perekonomian Papua Barat didominasi oleh kategori Industri Pengolahan (32,70 persen); Pertambangan dan Penggalian (27,13 persen); dan Pertanian, Kehutanan, dan Perikanan (11,82 persen); Konstruksi (7,76 persen); dan Administrasi Pemerintahan, Pertahanan dan Jaminan Sosial Wajib $(6,62$ persen). Pada tahun 2016 lima ketegori perekonomian yang mempunyai kontribusi terbesar di Papua Barat adalah Industri Pengolahan (26,40 persen); Pertambangan dan Penggalian (19,13 persen); Konstruksi (14,87 persen); Pertanian, Kehutanan, dan Perikanan (10,94 persen); dan Administrasi Pemerintahan, Pertahanan dan Jaminan Sosial Wajib (10,51 persen).

Kategori Industri Pengolahan dan Pertambangan dan Penggalian sangat mendominasi struktur perekonomian Papua Barat sejak tahun 2010.

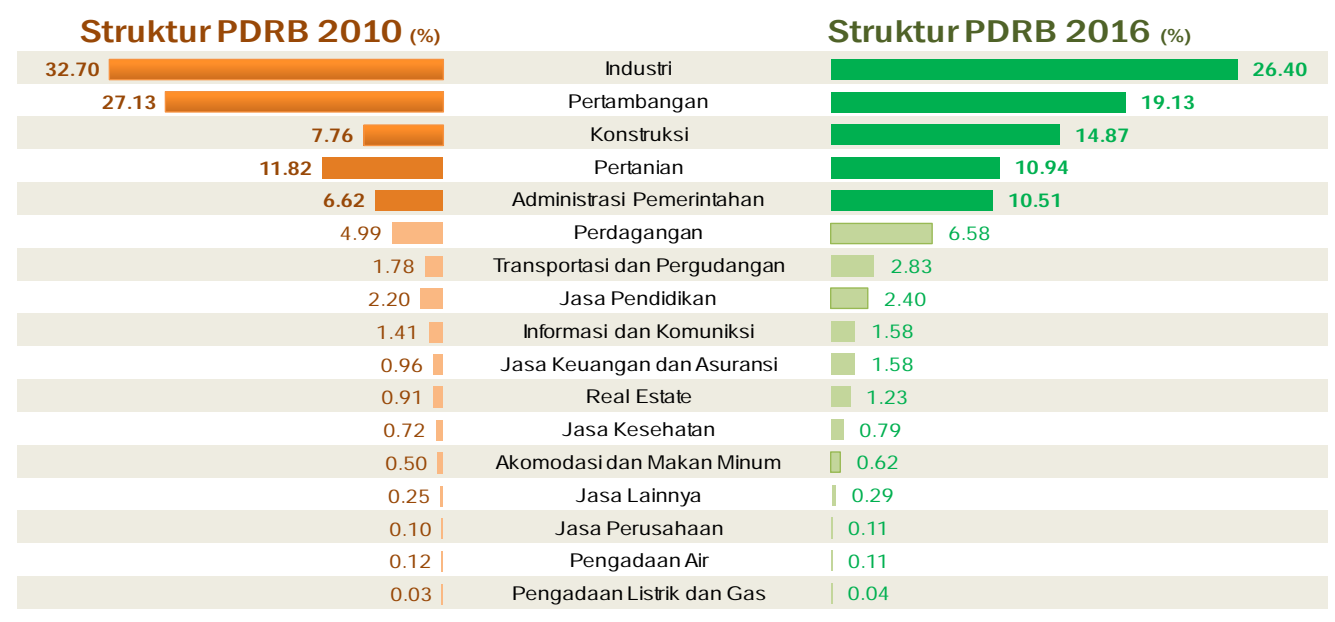

Gambar 2. Struktur Ekonomi Papua Barat Tahun 2010 dan 2016

Journal of Fiscal and Regional Economy Studies 
Adanya komoditas minyak dan gas bumi (migas) pada dua kategori lapangan usaha tersebut menyumbang lebih dari separuh PDRB Papua Barat. Komoditas migas dimaksud adalah gas alam cair atau Liquid Netrolium Gas (LNG) yang diproduksi oleh LNG Tangguh.

Peran kategori industri pengolahan dan pertambangan dan galian begitu besar terhadap pembentukan PDRB. Pertumbuhan ekonomi pada tahun 2010 sempat menyentuh angka 46,6 persen. Pertumbuhan tertinggi sejak Provinsi Papua Barat definitif sebagai daerah otonom baru. Setelah tahun 2010, pertumbuhan ekonomi Papua Barat terus melambat seiring dengan stagnasi produk gas alam cair LNG Tangguh. Terlebih dengan dikeluarkannya UndangUndang (UU) Nomor 4 Tahun 2009 tentang Pertambangan Mineral dan Batubara. Pada Pasal 170 dinyatakan bahwa pemegang Kontrak Karya wajib melakukan pemurnian mineral dalam negeri dalam jangka waktu 5 tahun sejak diundangkannya Undang-undang tersebut. Akibatnya, meski lapangan usaha Industri Pengolahan dan Pertambangan dan Penggalian masih mendominasi perekonomian Papua Barat tetapi besaran kontribusi dua kategori lapangan usaha ini hingga tahun 2016 semakin berkurang.

Faktor lain yang mempengaruhi penurunan kontribusi Industri Pengolahan dan Pertambangan dan Penggalian pada tahun 2016 karena semakin tingginya pertumbuhan kategori lapangan usaha lainnya. Kategori Konstruksi, Perdagangan Besar dan Eceran; Reparasi Mobil dan Sepeda Motor, Transportasi dan Pergudangan, dan Administrasi Pemerintahan, Pertahanan dan Jaminan Sosial Wajib mengalami pertumbuhan yang cukup tinggi.

Pergeseran struktur perekonomian Papua Barat juga terjadi pada pembentukan PDRB tanpa migas. Pada tahun 2010, struktur perekonomian Papua Barat didominasi oleh kategori Pertanian, Kehutanan, dan Perikanan (26,66 persen); Konstruksi (17,51 persen); Administrasi Pemerintahan, Pertahanan dan Jaminan Sosial Wajib (14,94 persen); Perdagangan Besar dan Eceran; Reparasi Mobil dan Sepeda Motor (11,27 persen); Industri Pengolahan (6,56 persen). Pada tahun 2016, kategori Konstruksi menjadi penyumbang terbesar PDRB Papua Barat yaitu sebesar 25,57 persen diikuti oleh kategori Pertanian, Kehutanan, dan Perikanan $(18,82$ persen); Administrasi Pemerintahan, Pertahanan dan Jaminan Sosial Wajib $(18,08)$; Perdagangan Besar dan Eceran; Reparasi Mobil dan Sepeda Motor (11,31); dan Transportasi dan Pergudangan (4,86 persen).

Kontribusi kategori Konstruksi yang sangat dominan pada pembentukan struktur perekonomian Papua Barat tahun 2016 mengindikasikan beberapa hal berikut. Pertama, pembangunan infrastruktur kantor-kantor pemerintahan, jalanjalan penghubung antar kabupaten, bandara, pelabuhan serta pembangunan-pembangunan lainnya terus menerus dilakukan sampai saat ini. Kedua, pembiayaan pembangunan infrastruktur didominasi oleh pemerintah. Hal ini terkait dengan 18,08 persen pembentukan PDRB tanpa migas tahun 2016 disumbang oleh kategori Administrasi Pemerintahan, Pertahanan dan Jaminan Sosial.
Struktur PDRB $2010(\%)$

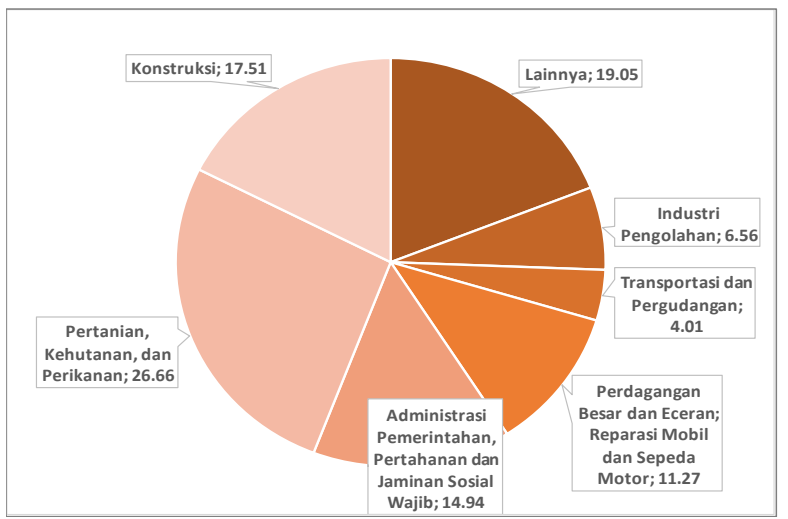

Struktur PDRB $2016(\%)$

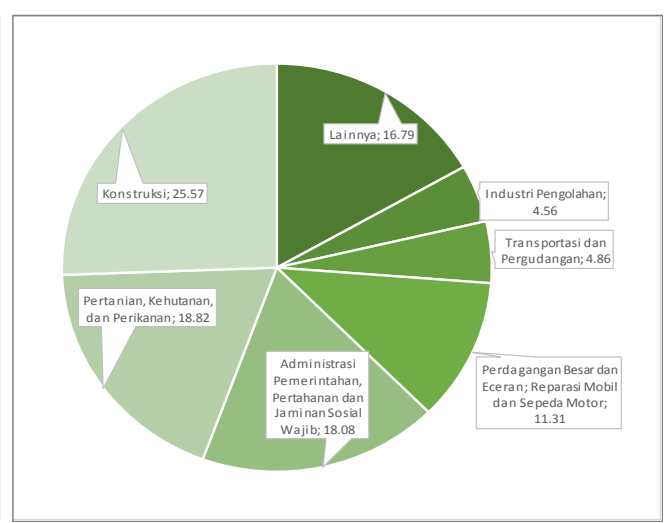

Gambar 3. Struktur PDRB Tanpa Migas Tahun 2010 dan 2016

Journal of Fiscal and Regional Economy Studies 
Selain Konstruksi, Kategori Pertanian, Kehutanan, dan Perikanan juga memberikan kontribusi yang cukup besar terhadap struktur perekonomian Papua Barat pada tahun 2016. Kontribusi kategori ini sebesar 18,82 persen pada tahun 2016. Urgensi pembangunan kategori Pertanian, Kehutanan, dan Perikanan di Papua Barat terkait dengan: 1) daya serap tenaga kerja tertinggi yaitu 39,50 persen pada tahun 2016; dan 2) Sasaran pembangunan nomor 25, 26, dan 27 RPJMD Provinsi Papua Barat tahun 2012 sampai dengan 2016 yaitu terwujudnya ketahanan pangan wilayah dengan peningkatan produktivitas pertanian, perikanan, dan peternakan; meningkatnya kegiatan perkebunan rakyat; meningkatnya pemanfaatan sumber daya hutan.

\section{Struktur dan Pertumbuhan PDRB Menurut Pengeluran}

PDRB menurut pengeluaran terdiri dari konsumsi akhir rumah tangga, konsumsi akhir LNPRT, konsumsi akhir pemerintah, pembentukan modal tetap bruto (PMTB), ekspor neto (ekspor dikurangi impor). Dengan mengetahui struktur PDRB dari sisi pengeluaran maka akan diketahui pula peranan kelembagaan dalam menggunakan barang dan jasa yang dihasilkan oleh berbagai sektor ekonomi.

PDRB Papua Barat pada tahun 2016 mencapai 66,64 triliun rupiah. Dari total PDRB tersebut terdapat empat komponen pengeluaran terbesar yang membentuknya. Pertama, pengeluaran ekspor ke luar negeri mencapai 23,36 triliun rupiah (35\%). Kedua, pengeluaran konsumsi rumah tangga mencapai 18,54 triliun rupiah (27\%). Ketiga, pengeluaran konsumsi pemerintah mencapai 14,76 triliun rupiah (22\%). Keempat, pembentukan modal tetap bruto mencapai 13,99 triliun rupiah (21\%). Sementara net ekspor antar daerah defisit $-5,97$ triliun rupiah.

Selama tahun 2010 - 2016 terdapat pergeseran distribusi komponen pengeluaran PDRB. Pergeseran terbesar terdapat pada komponen pengeluaran pemerintahah dan pembentukan modal tetap bruto. Pada tahun 2010, share komponen pengeluaran pemerintah 16,40 persen dari total PDRB sebesar 41,36 triliun rupiah. Pada tahun 2016, share komponen ini bertambah 5,75 poin menjadi 22,15 persen dari total $\mathrm{PDRB}$ sebesar 66,64 triliun rupiah. Seiring dengan pertambahan kontribusi komponen pengeluaran pemerintah ini diikuti oleh pertambahan share komponen pengeluaran untuk pembentukan modal tetap bruto dari 16,57 persen pada tahun 2010 menjadi 21 persen pada tahun 2016 .

Besarnya share komponen pengeluaran pemerintah dan pembentukan modal bruto selama tahun 2010 - 2016 berkaitan dengan fokus pembangunan fisik di Provinsi Papua Barat. Kantor Gubernur Papua Barat berlantai 5 yang terletak di bukit Arfai II, Manokwari, diresmikan oleh Menteri Dalam Negeri Tjahjo Kumolo, Senin, 19 Oktober 2015. Kantor dengan luas 26.663 meter persegi tersebut dibangun menggunakan anggaran tahun jamak selama 12 tahun

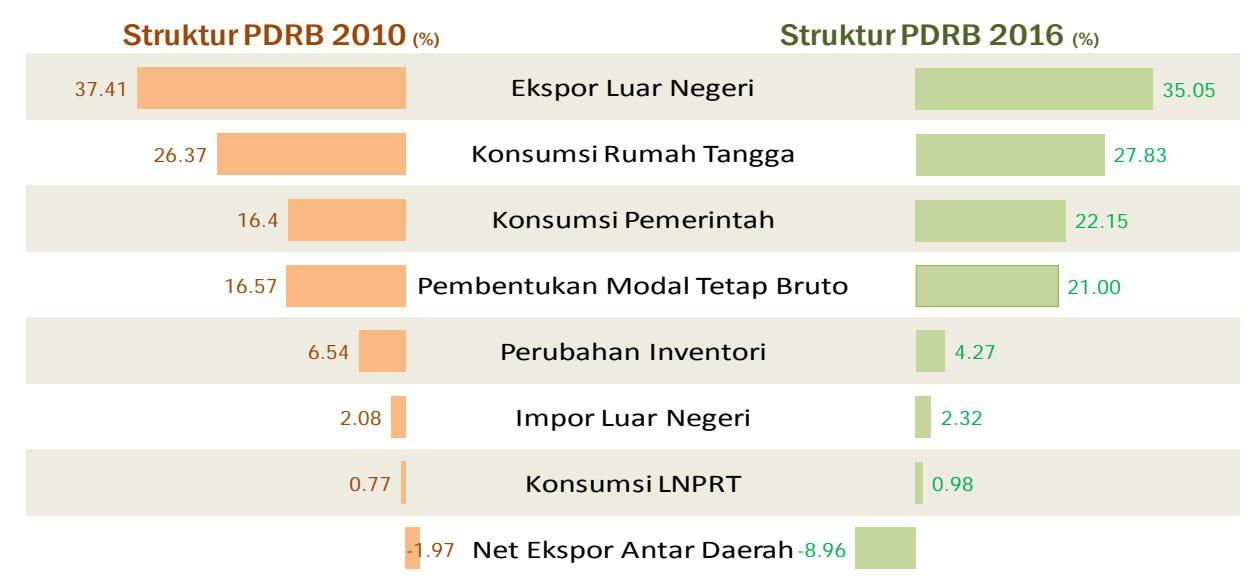

Gambar 4. Struktur PDRB Pengeluaran Tahun 2010 dan Tahun 2016 
yang mencapai hampir setengah triliun atau 445 miliar rupiah. Demikian juga dengan proyek pembangunan jalan trans Papua Barat - Papua turut berkontribusi pada besarnya pengeluaran konsumsi pemerintah sekaligus pembentukan modal tetap bruto. Jalan Trans-Papua adalah jalan nasional yang menghubungkan Provinsi Papua Barat dan Provinsi Papua, membentang dari Kota Sorong di Provinsi Papua Barat hingga Merauke di Provinsi Papua dengan total panjang mencapai 4.330,07 kilometer $(\mathrm{km})$. Dari total panjang tersebut, terbagi atas $3.259,45 \mathrm{~km}$ di Provinsi Papua dan 1.070,62 km di Provinsi Papua Barat. Alokasi untuk Papua Barat, pada tahun 2015 untuk alokasi infrastruktur jalan dan jembatan Rp 2,48 triliun. Tahun 2016 alokasi Papua Barat sebesar $\mathrm{Rp}$ 1,28 triliun untuk infrastruktur jalan dan jembatan.

Peran komponen ekspor dalam pembentukan PDRB Pengeluaran di Papua Barat sangat dominan. Komoditas unggulan yang menjadi barang ekspor antara lain gas alam cair; Kakau, Coklat; Bijih, Kerak, dan Abu Logam; Perhiasan atau permata; Kayu, barang dari Kayu; dan Ikan dan Udang. Total ekspor Papua Barat pada tahun 2016 mencapai 45,38 triliun rupiah. Ekspor terbesar berupa gas alam cair. Tiga negara tujuan utama ekspor Papua Barat adalah Jepang, Tiongkok dan Korea Selatan. Sebesar 99,81 persen ekspor Papua Barat bersumber dari migas.

\section{PDRB Per Kapita}

PDRB per kapita adalah rata-rata pendapatan yang diterima oleh setiap penduduk di suatu wilayah selama satu tahun. Indikator ini diguna- kan untuk menggambarkan tingkat kemakmuran masyarakat secara makro. Semakin tinggi pendapatan yang diterima penduduk di suatu wilayah maka tingkat kesejahteraan di wilayah yang bersangkutan dapat dikatakan bertambah baik. PDRB per kapita diperoleh dengan cara membagi PDRB dengan jumlah penduduk pertengahan tahun.

Tren PDRB per kapita di Provinsi Papua Barat dapat dilihat pada Tabel 1, terlihat bahwa PDRB per kapita Provinsi Papua Barat mengalami peningkatan pada setiap tahunnya. Pada tahun 2012, PDRB atas dasar harga berlaku per kapita Provinsi Papua Barat adalah sebesar Rp 58,76 juta per orang, kemudian meningkat menjadi Rp 74,59 juta per orang pada tahun 2016. PDRB per kapita tersebut tampak sangat besar. Hal ini disebabkan karena dominasi PDRB Papua Barat adalah dari kategori industri pengolahan di mana salah satu sumber utamanya adalah produksi gas dari LNG tangguh. PDRB per kapita dengan menyertakan Migas di dalamnya menghasilkan indikator semu karena tidak menggambarkan kemakmuran masyarakat Papua Barat seutuhnya.

Dengan meniadakan pengaruh Migas pada PDRB atas dasar harga berlaku, PDRB per kapita Papua Barat tidaklah sebesar di atas. PDRB per kapita tahun 2016 terkoreksi menjadi 43,36 juta rupiah per orang per tahun. Terdapat selisih hingga 31,23 juta rupiah per kapita per tahun antara PDRB per kapita. dengan migas dan tanpa migas. Hal ini menandakan bahwa investasi yang bersumber dari penanaman modal asing mendongkrak PDRB sangat besar tetapi kurang berdampak pada peningkatan tingkat kesejahteraan penduduk.

Tabel 1. PDRB ADHB Per Kapita Papua Barat Tahun 2012 - 2016

\begin{tabular}{|c|c|c|c|c|c|}
\hline Uraian & 2012 & 2013 & 2014 & 2015 & 2016 \\
\hline Penduduk & 806.995 & 828.293 & 849.809 & 871.510 & 893.362 \\
\hline PDRB Dengan Migas ADHB (Juta Rp) & 47.421 .091 & 52.997 .659 & 58.180 .964 & 62.889 .889 & 66.635 .513 \\
\hline PDRB Tanpa Migas ADHB (Juta Rp) & 23.151 .730 & 26.637 .142 & 30.670 .155 & 34.900 .590 & 38.736 .574 \\
\hline $\begin{array}{l}\text { PDRB Dengan Migas ADHB Per } \\
\text { Kapita (Juta Rp) }\end{array}$ & 58,76 & 63,98 & 68,46 & 72,16 & 74,59 \\
\hline $\begin{array}{l}\text { PDRB Tanpa Migas ADHB Per Kapita } \\
\text { (Juta Rupiah) }\end{array}$ & 28,69 & 32,16 & 36,09 & 40,05 & 43,36 \\
\hline
\end{tabular}

Sumber: BPS Provinsi Papua Barat, 2016 


\section{Efisiensi Belanja Daerah}

Pengertian efisiensi berhubungan dengan konsep produktifitas, dengan menggunakan perbandingan antara output yang dihasilkan terhadap input yang digunakan (cost of output). Proses kegiatan operasional dapat dikatakan efisien apabila suatu produk atau hasil kerja tertentu dapat dicapai dengan penggunaan sumber daya dan dana yang serendah-rendahnya (spending well). Alokasi belanja seperti pada tabel 2 diharapkan dapat meningkatkan Pertumbuhan ekonomi, penurunan jumlah kemiskinan, peningkatan lapangan pekerjaan/penurunan angka pengangguran penduduk serta distribusi pendapatan yang semakin sempit di Papua Barat. Berdasarkan data BPS bahwa laju pertumbuhan PDRB cenderung mengalami penurunan padahal alokasi belanja selama tahun 2012 s.d 2016 mengalami peningkatan. Dapat dikatakan bahwa laju pertumbuhan ekonomi Papua Barat mengalami perlambatan selama lima tahun terakhir.

Tabel 2. Porsi Alokasi Belanja Terhadap Masing-Masing Urusan Selama Tahun 2012 - 2016

\begin{tabular}{|c|c|c|c|c|c|c|}
\hline \multirow{2}{*}{ No } & \multirow{2}{*}{ Urusan } & \multicolumn{5}{|c|}{ Tahun (\%) } \\
\hline & & 2012 & 2013 & 2014 & 2015 & 2016 \\
\hline & Pendidikan & 2,01 & 1,70 & 2,01 & 1,29 & 2,25 \\
\hline & Kesehatan & 1,69 & 1,79 & 2,98 & 2,91 & 3,04 \\
\hline & Pekerjaan Umum & 10,73 & 10,74 & 13,67 & 17,07 & 18,00 \\
\hline & Perumahan & 0,00 & 0,09 & 0,41 & 0,53 & 1,79 \\
\hline 5 & Penataan Ruang & 0,10 & 0,22 & 0,08 & 0,15 & 9,47 \\
\hline 6 & Perencanaan Pembangunan & 1,12 & 1,02 & 0,72 & 0,69 & 0,50 \\
\hline & Perhubungan & 2,38 & 2,08 & 2,54 & 1,19 & 1,89 \\
\hline & Lingkungan Hidup & 0,44 & 0,51 & 0,40 & 0,37 & 0,30 \\
\hline 10 & Kependudukan dan Catatan Sipil & 0,45 & 0,35 & 0,34 & 0,27 & 0,27 \\
\hline & Pemberdayaan Perempuan & 0,53 & 0,52 & 0,42 & 0,36 & 0,33 \\
\hline & Sosial & 0,79 & 0,53 & 0,51 & 0,57 & 0,52 \\
\hline & Tenaga Kerja & 0,10 & 0,00 & 0,03 & 0,06 & 0,03 \\
\hline & Koperasi dan Usaha Kecil Menengah & 0,76 & 0,42 & 0,43 & 0,52 & 0,32 \\
\hline & Penanaman Modal & 0,29 & 0,25 & 0,34 & 0,39 & 0,31 \\
\hline & Pariwisata & 0,06 & 0,26 & 0,15 & 0,00 & 0,00 \\
\hline & Kebudayaan dan Pariwisata & 0,00 & 0,36 & 0,40 & 0,32 & 0,39 \\
\hline & Pemuda dan Olah Raga & 0,01 & 0,62 & 1,68 & 0,39 & 0,36 \\
\hline & Kesatuan Bangsa dan Politik Dalam Negeri & 0,01 & 0,48 & 0,33 & 1,27 & 1,15 \\
\hline & Pemerintahan Umum & 73,83 & 67,10 & 61,84 & 63,17 & 59,28 \\
\hline & Pemberdayaan Masyarakat dan Desa & 1,71 & 1,39 & 0,98 & 1,54 & 1,33 \\
\hline & Kearsipan & 0,09 & 0,13 & 0,14 & 0,00 & 0,00 \\
\hline & Komunikasi dan Informatika & 0,29 & 0,23 & 0,26 & 0,00 & 0,24 \\
\hline & Ketahanan Pangan & 0,37 & 0,37 & 0,28 & 0,23 & 0,26 \\
\hline & Perpustakaan & 0,50 & 0,58 & 0,19 & 0,27 & 0,39 \\
\hline & Pertanian & 0,85 & 0,97 & 1,02 & 1,07 & 1,08 \\
\hline & Kehutanan & 0,87 & 0,61 & 0,47 & 0,76 & 0,87 \\
\hline & Energi dan Sumberdaya Mineral & 0,68 & 1,72 & 1,43 & 0,54 & 0,41 \\
\hline & Kelautan dan Perikanan & 0,97 & 1,16 & 2,36 & 2,58 & 2,45 \\
\hline & Perdagangan & 0,14 & 0,50 & 0,20 & 0,22 & 0,20 \\
\hline & Perindustrian & 0,33 & 0,37 & 0,33 & 0,19 & 0,25 \\
\hline & Transmigrasi & 0,24 & 0,00 & 0,28 & 0,28 & 0,00 \\
\hline
\end{tabular}


Kalau dilihat dari penyerapan tenaga kerja di Provinsi Papua Barat menunjukkan bahwa jumlah pengangguran mengalami penurunan hingga tahun 2014. Meningkatnya alokasi belanja belum mampu menurunkan jumlah pengangguran hingga tahun 2016. Jumlah pengangguran mengalami peningkatan sejak tahun 2015 hingga saat ini, makin bertambahnya jumlah pengangguran akibat pertambahan jumlah penduduk melalui migrasi penduduk dari daerah lain (data migrasi penduduk). Awal otonom khusus dan pembentukan Provinsi Papua Barat kesenjangan pengeluaran penduduk masih sangat rendah dengan nilai gini saat itu masih di bawah 0,3. Bertumbuhnya aktivitas ekonomi hinga saat ini, indeks gini mulai bergerak naik hingga saat ini mencapai 0.39. Kondisi ini menunjukkan bahwa alokasi belanja selama 5 tahun terakhir ini hanya tahun 2014 yang telah menurunkan angka indeks gini.
Lambatnya penurunan kemiskinan di Papua Barat disebabkan tingginya Garis Kemiskinan (GK dibentuk oleh GK Makanan dan GK Non Makanan). Share GK Makanan masih sangat dominan. Terjadinya inflasi terhadap komoditas makanan akan sangat berpengaruh terhadap kenaikan garis kemiskinan. Selama 10 tahun terakhir, GK Papua Barat tumbuh 142,61 persen, dengan rata-rata kenaikan GK setiap tahun mencapai 5,80 persen.

Pertumbuhan pengeluaran per kapita per bulan mencapai 177,63 persen pada periode yang sama dengan pertumbuhan per tahun sebesar 13,73 persen. Meskipun terdapat kenaikan garis kemiskinan setiap tahunnya namun selalu diimbangi oleh kenaikan rata-rata pengeluaran per kapita per bulan oleh penduduk Papua Barat karena rata-rata pendapatan perkapita bertambah seperti gambar 7.

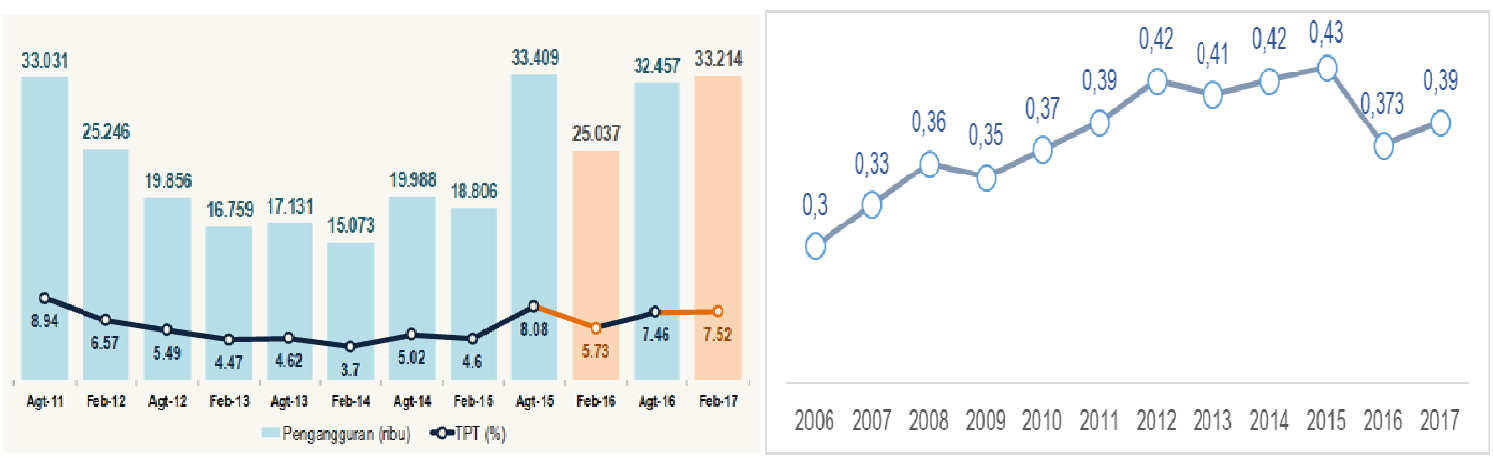

Gambar 6. Perkembangan Pengangguran dan Gini Rasio Provinsi Papua Barat

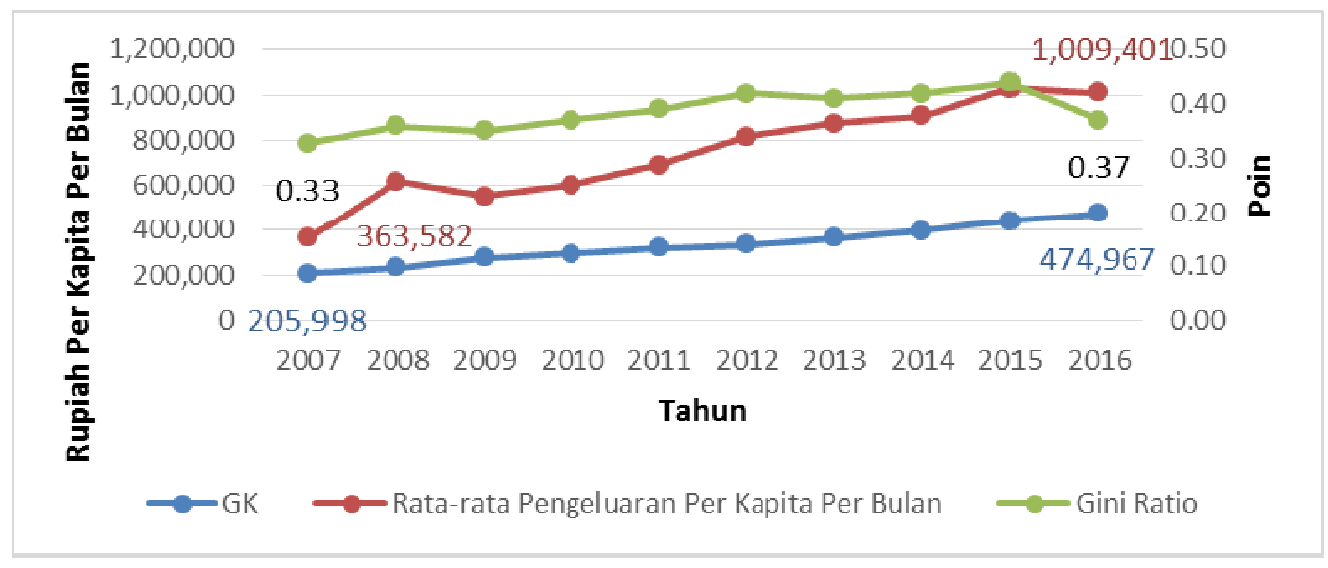

Gambar 7. Hubungan antara Garis Kemiskinan, Rata-rata Pengeluaran dan Gini Rasio 
Lambannya penurunan tingkat kemiskinan di Papua Barat karena tingkat ketimpangan pendapatan yang cenderung meningkat selama kurun 2007 - 2017. Tingkat ketimpangan pengeluaran Papua Barat masuk dalam kategori sedang dalam arti kontribusi pengeluaran didominasi oleh kelompok sedang dan kelompok atas. Dapat dikatakan bahwa, hasil-hasil pembangunan di Papua Barat lebih banyak dinikmati oleh kelompok menengah dan kelompok atas.

Guna memperlancar proses pembangunan di Provinsi Papua Barat, pemerintah menyusun dan melakukan kebijakan anggaran, hal ini karena pemerintah menginginkan Provinsi Papua Barat menjadi suatu daerah yang makmur, mandiri dan rakyatnya hidup sejahtera. Dalam melaksanakan kebijakan tersebut terdapat kendala-kendala yang dianggap menjadi tantangan fiskal yang ada di Provinsi Papua Barat, kendala tersebut yaitu:

\section{Sumber Daya Manusia}

Perkembangan kuantitas sumber daya manusia dapat menjadi pendorong maupun penghambat pembangunan. Perkembangan kuantitas penduduk yang cepat tidak disertai dengan peningkatan kualitas penduduk dapat menjadi penghambat dalam pembangunan ekonomi. Karena kuantitas penduduk yang tinggi dengan kualitas yang tinggi dapat meningkatkan produksi yang dihasilkan secara agregat, yang pada akhirnya menggerakkan roda perekonomian tinggi.

Dari data yang dirilis BPS Provinsi Papua Barat, laju pertumbuhan penduduk tertinggi berada di kota Sorong sebesar 4,38\% sedangkan terendah di Kabupaten Tambrauw sebesar 2,02\%. Sedangkan untuk Kabupaten Manokwari memiliki laju pertumbuhan penduduk kelima yaitu $3,72 \%$.

Sebaran penduduk di Provinsi Papua Barat, sebaran tertinggi di Kota Sorong sebanyak 25,31\% dan Kabupaten Manokwari sebanyak $24,74 \%$. Berdasarkan latar belakang pendidikan terakhir, persentase penduduk yang bekerja sebagian besar berpendidikan rendah. Rilis BPS Provinsi Papua Barat 43,53\% penduduk yang bekerja berlatar belakang pendidikan rendah sedangkan 11,21\% yang berpendidikan diploma dan sarjana.

\section{Infrastruktur}

Provinsi Papua Barat yang terdiri dari 13 Kabupaten/Kota dengan luas daerah 97.024,37 $\mathrm{km}^{2}$ dimana infrastruktur menjadi salah satu faktor penghambat pembangunan dan juga menjadi tantangan fiskal di Provinsi Papua Barat. Terlihat bahwa kurangnya infrastruktur serta sarana dan prasarana yang baik di Provinsi Papua Barat menjadi penghambat masuknya investor untuk berinvestasi di Papua Barat. Sehingga saat ini salah satu yang dilaksanakan adalah perbaikan infrstruktur disegala bidang baik dari transportasi darat yaitu pembukaan jalan penghubung antar kabupaten, transportasi laut yaitu perbaikan dan pembuatan pelabuhan kapal yang permanen dan transportasi udara yaitu pembukaan bandar udara perintis di seluruh kabupaten baru. Diharapakan dengan perbaikan infrastruktur maka pertumbuhan ekonomi diseluruh daerah di Provinsi Papua Barat akan cepat berkembangan.

\section{Sarana Komunikasi dan Informasi, Serta Jaringan Listrik}

Ketersediaan sarana komunikasi dan Informasi, serta jaringan listrik sangat penting dalam perkembangan suatu daerah. Untuk saat ini salah satu kendala pembangunan di Provinsi Papua Barat adalah rendahnya ketersediaan sarana komunikasi dan informasi serta jaringan listrik. Kurangnya sarana tersebut berdampak pada lambatnya diperoleh informasi yang dapat dijadikan acuan untuk perkembangan suatu daerah. Contohnya, Kabupaten Tambrauw, Kabupaten Teluk Bintuni, Kabupaten Sorong Selatan, dan Kabupaten Teluk Wondama sarana informasi dan jaringan listrik sangat minim, sehingga pelayanan kepada masyarakat menjadi lambat, dan daya tarik bagi investor menjadi rendah.

\section{Pertumbuhan Ekonomi dan Ketimpangan Distribusi Pendapatan}

Pertumbuhan PDRB menggambarkan pertumbuhan ekonomi di suatu wilayah. Selama beberapa tahun terakhir laju pertumbuhan PDRB di Provinsi Papua Barat cenderung menurun dengan disertai kesenjangan distribusi pendapatan. Hal itu disebabkan kontribusi pertumbuhan utama disumbang oleh sumberdaya alam atau yang menerima manfaat pertumbuhan 
ekonomi adalah sebagian kecil lapisan masyarakat. Indikator pertumbuhan ekonomi (PDRB) yang diikuti dengan tingginya kesenjangan distribusi pendapatan ditunjukkan oleh angka Gini Ratio beberapa daerah di Papua Barat .

\section{Pertanian}

Sebagian besar daerah di Papua Barat kontribusi lapangan usaha pertanian terhadap PDRB daerah masing-masing sangat tinggi, hal ini mengindikasikan bahwa sumber utama pendapatan sebagaian besar masyarakat dihasilkan dari sektor pertanian. Namun daerah yang kontribusi lapangan usaha pertanian terhadap PDRB daerah masing-masing tinggi, apabila dibandingkan dengan lapangan usaha pertanian PDRB provinsi kontribusinya sangat rendah.

Kebijakan alokasi anggaran belanja negara pada APBN tahun 2012 diarahkan kepada upaya mendorong pertumbuhan di daerah melalui pengembangan koridor ekonomi, membangun infrastruktur yang mendukung terwujudnya keterhubungan wilayah (globally connected and domestically integrated) dan mendorong percepatan pembangunan di Papua Barat. Dampak dari kebijakan tersebut, yaitu Kementerian Pekerjaan Umum dan Kementerian Perhubungan merupakan kementerian yang alokasi Belanja Modal DIPA terbesar di Papua Barat, yaitu secara agregat pada tahun 2011 sebesar 83\%, tahun 2012 sebesar 88,69\%, tahun 2013 sebesar $84,55 \%$ dan tahun 2014 sebesar $91,84 \%$.
Kebijakan terwujudnya keterhubungan wilayah sangat mendukung lapangan usaha pertanian karena petani dapat lebih mudah memasarkan hasil pertanian. Oleh karena itu perlu dipikirkan untuk meningkatkan alokasi di sektor pertanian, sehingga keterhubungan antar wilayah tersebut dapat dirasakan manfaatnya oleh masyarakat petani.

\section{Efektifitas Belanja Daerah}

Efektifitas pada dasarnya berhubungan dengan pencapaian tujuan atau target kebijakan (hasil guna). Efektifitas merupakan hubungan antara keluaran dengan tujuan dan sasaran yang harus dicapai. Kegiatan operasional dikatakan efektif apabila proses kegiatan mencapai tujuan dan sasaran akhir kebijakan (spending wisely). Indikator efektifitas menggambarkan jangkauan akibat dan dampak (outcome) dari keluaran (output) program dalam mencapai tujuan program (Mardiasmo 2009).

Alokasi belanja berdasarkan urusan yang telah dikonversi kedalam sektor ekonomi menunjukkan bahwa porsi administrasi pemerintahan lebih mendominasi yang secara nominal selama 5 tahun mengalami peningkatan seperti pada Lampiran 2. Pengalokasian belanja di Provinsi Papua Barat memiliki kriteria efektifitas yang bervariasi selama tahun 2012 sampai dengan tahun 2016. Pada tahun 2011 sampai tahun 2016 tingkat efektifitas berada dalam kriteria yang

Tabel 3. Proporsi Alokasi Belanja Berdasarkan Urusan

\begin{tabular}{clccccc}
\hline \multirow{2}{*}{ No Ususan } & \multicolumn{5}{c}{ Tahun (\%) } \\
\cline { 3 - 7 } & & $\mathbf{2 0 1 2}$ & $\mathbf{2 0 1 3}$ & $\mathbf{2 0 1 4}$ & $\mathbf{2 0 1 5}$ & $\mathbf{2 0 1 6}$ \\
\hline 1 & Pertanian, Kehutanan, dan Perikanan & 2,98 & 3,21 & 4,24 & 4,68 & 4,32 \\
2 & Pertambangan dan Galian & 0,67 & 1,78 & 1,47 & 0,54 & 0,38 \\
3 & Perdagangan & 0,13 & 0,51 & 0,21 & 0,22 & 0,19 \\
4 & Konstruksi & 12,81 & 13,21 & 16,68 & 18,41 & 18,47 \\
5 & Industri Pengolahan & 0,32 & 0,38 & 0,34 & 0,19 & 0,23 \\
6 & Real estate & 0,00 & 0,09 & 0,42 & 0,53 & 1,66 \\
7 & Administrasi Pemerintahan, & 73,81 & 70,54 & 64,60 & 65,24 & 56,30 \\
8 & Informasi dan Komunikasi & 0,28 & 0,23 & 0,27 & 0,00 & 0,22 \\
9 & Jasa Pendidikan & 2,47 & 2,99 & 4,00 & 1,96 & 2,78 \\
10 & Jasa Kesehatan dan Kegiatan Sosial & 2,42 & 2,40 & 3,59 & 3,51 & 3,31 \\
11 & Jasa Keuangan & 1,02 & 0,69 & 0,79 & 0,92 & 0,58 \\
12 & Jasa Lainnya & 3,08 & 3,97 & 3,40 & 3,79 & 11,56 \\
\hline & Total & $\mathbf{1 0 0 , 0 0}$ & $\mathbf{1 0 0 , 0 0}$ & $\mathbf{1 0 0 , 0 0}$ & $\mathbf{1 0 0 , 0 0}$ & $\mathbf{1 0 0 , 0 0}$ \\
\hline
\end{tabular}




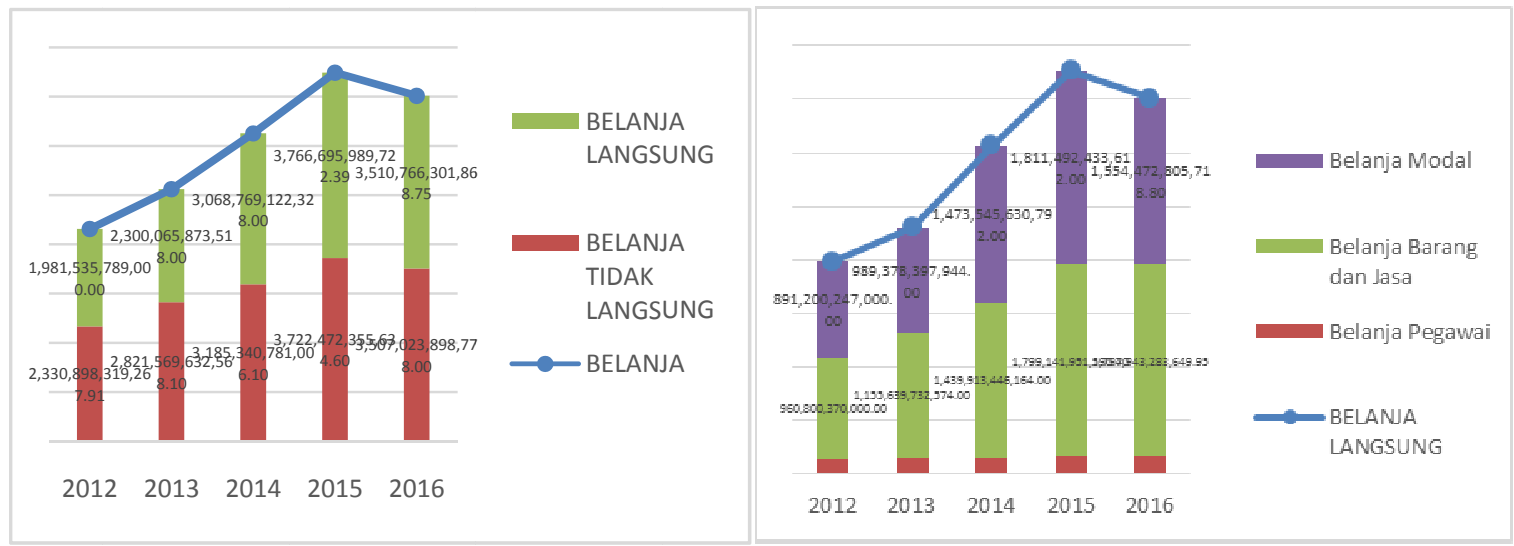

Gambar 9. Klasifikasi Jenis Belanja (Dalam Milyar Rupiah)

kurang efektif karena realisasi anggaran masih jauh perbedaan dengan target anggaran. Tahun 2014 sampai tahun 2015 tingkat efektifitas sudah bisa masuk dalam kriteria cukup efektif. Walau masuk dalam kriteria cukup efektif, realisasi anggaran yang di capai masih cukup jauh perbedaannya untuk memenuhi target anggaran yang ditetapkan. Menurut para Pejabat anggaran yang cukup jauh perbedaannya dengan target yang diharapkan disebabkan oleh adanya kegiatan yang dianggarkan, tetapi tidak dapat dilaksanakan.

Alokasi belanja berdasarkan sektor ekonomi dalam PDRB menunjukkan bahwa Administrasi pemerintahan mendapatkan alokasi sampai 73,81 persen dari total belanja pada tahun 2012 sebesar Rp. 4,3 milyar. Alokasi tersebut secara nominal bertambah setiap tahunnnya hingga haun 2016 walaupun secara proporsional mengalami penurunan hingga 56,3 persen.

Alokasi Belanja modal dibutuhkan utuk pembangunan infrastruktur yang lebih tinggi seperti pembangunan jalan provinsi dan pembukaan jalan baru untuk mengatasi masalah konektivitas daerah. Selama lima tahun terakhir terlihat alokasi belanja modal terus melonjak tajam bila dibandingkan dengan belanja subsidi atau belanja bantuan sosial yang lebih bersifat konsumtif. Belanja modal sebagai indikator perkembangan sektor produktif terutama bertujuan agar mendorong perkembangan sektor konsumtif misalnya pembangunan pasar untuk meningkatkan jual beli barang bagi masyarakat di pedesaan maupun perkotaan.
Berdasarkan Tabel Input Output Papua Barat tahun 2013, bahwa output daerah Papua Barat bersumber dari sektor ekonomi berikut (Gambar $10)$.

Berdasarkan alokasi belanja menunjukkan bahwa peningkatan belanja terhadap sektorsektor yang memberikan kontribusi yang besar akan memberikan tambahan output yang lebih besar sehingga dapat memberikan kontribusi yang berarti bagi pertumbuhan ekonomi Provinsi Papua Barat.

Sektor yang mempunyai derajat kepekaan tinggi memberi indikasi bahwa sektor tersebut mempunyai keterkaitan ke depan atau mempunyai daya dorong yang cukup kuat dibandingkan dengan sektor lain. Kesepuluh sektor tersebut yakni Sektor Ikan dengan Indeks Derajat Kepekaan (IDK) 1,574; disusul berturut-turut Industri Barang Kayu dan Hasil Hutan sebesar 1,481; Perdagangan Besar dan Eceran, Bukan Mobil dan Sepeda Motor, Bukan Mobil dan Sepeda Motor 1,446; Listrik, Gas dan Air Bersih 1,347; Pertambangan dan Penggalian 1,272; Perkebunan 1,267; Konstruksi 1,184; Infokom 1,176; Keuangan dengan 1,147; dan Padi IDK 1,105. Artinya sektor pertanian (yang di fokuskan pada perikanan, kehutanan, perkebunan dan tanaman pangan padi) merupakan sektor yang dapat mendorong sektor-sektor ekonomi lainnya, begitu pula perdagangan, kontruksi dan jasa keuangan. 


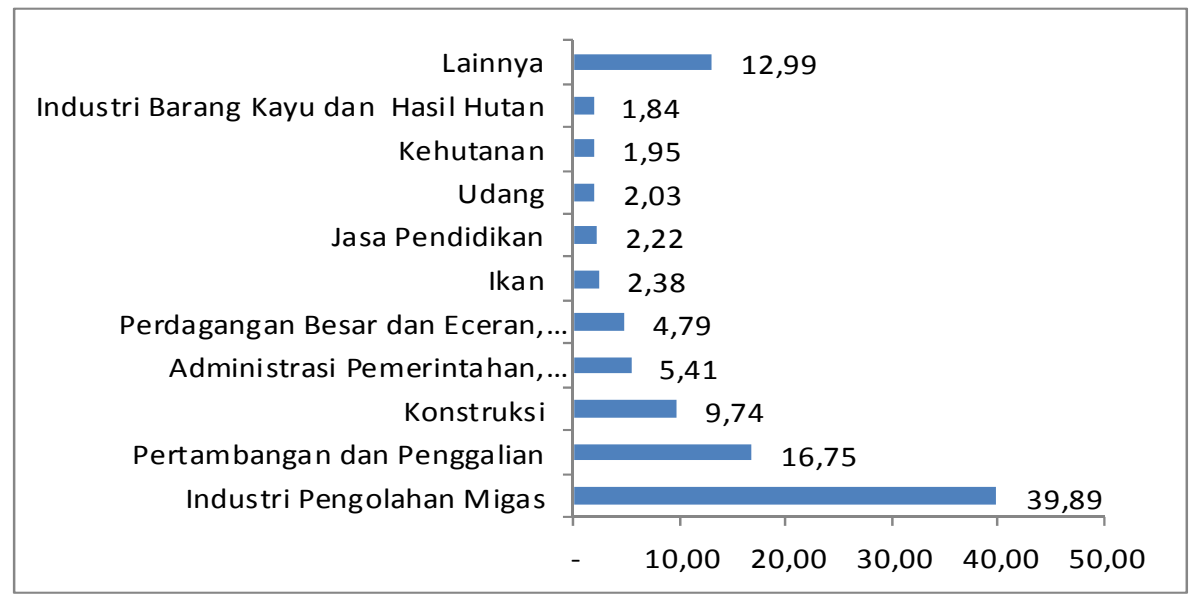

Gambar 10. Komposisi Output Provinsi Papua Barat

Sektor yang memberikan Angka pengganda pendapatan menunjukkan bahwa bahwa tersebut dapat memberikan efek maksimal terhadap peningkatan pendapatan penduduk di Provinsi Papua Barat. Administrasi Pemerintahan, Pertahanan dan Jaminan Sosial Wajib yaitu sebesar 0,716 menunjukkan bahwa peningkatan permintaan akhir atas output sektor tersebut sebesar 1 juta rupiah berdampak pada peningkatan pendapatan di seluruh sektor sebesar 716 ribu rupiah. Artinya peningkatan alokasi belanja selama 5 tahun terakhir yang menyebabkan peningkatan pendapatan penduduk di Provinsi Papua Barat. Begitu halnya pula dengan jasa pendidikan, jasa lainnya, konstruksi, pertanian dan perdagangan.

Sektor yang meberikan penyerapan tenaga kerja yang tinggi adalah Pertanian, jasa lainnnya dan industri artinya alokasi belanja pada sektor tersebut dapat meningkatkan penyerapan tenaga kerja bagi penduduk di Papua Barat. Tenaga kerja yang terbentuk ketika Ekspor mencapai sekitar 146 ribu yang didominasi oleh sektor pertanian, perdagangan dan jasa.Peningkatan eksport akan memacu ketiga sektor tersebut artinya dengan tambahan alokasi belanja pada sektor-sektor tersebut dapat meningkatkan penyerapan tenaga kerja.

\section{KESIMPULAN}

Berdasarkan uraian analisis ekonomi dan fiskal di Provinsi Papua Barat maka beberapa kesimpulan yang dapat di tarik yaitu:
1) Selama 5 tahun terakhir pertumbuhan ekonomi mengalami perlambatan disebabkan ketergantungan perekonomian Papua Barat lebih didominasi oleh sektor migas, pertambangan yang selama kurun waktu tersebut mengalami penurunan output.

2) Indikator pembanguan tingkat pengangguran cenderung menurun dan berfluktuasi disebabkan oleh menurunnya jumlah eksport pada sektor sektor migas dan pertambangan sehingga mempengaruhi penyerapan tenaga kerja pada semua sektor dan terjadi peningkatan output pada sektor pertanian, konstruksi dan administrasi pemerintah serta jasa lainnnya.

3) Peningkatan alokasi belanja modal selama 5 tahun terakhir tidak konsisten dan lebih banyak dialokasikan untuk pengadaan mesin, bangunan dan tanah sehingga kurang memberikan dorongan terhadap penciptaan output pada sektor-sektor yang produktif,

4) Alokasi belanja terhadap sektor strategis pertanian hanya $3 \mathrm{~s}, \mathrm{~d} 4.6$ persen dari alokasi belanja selama 5 tahun yang mengakibatkan pendapatan golongan menengah kebawah mengalami stagnan, 5) Efektifitas alokasi belanja kurang sinkron dengan tujuan yang dicapai karena alokasi belanja lebih didominasi oleh belanja administrasi pemerintah.

\section{DAFTAR PUSTAKA}

Badan Pusat Statistik, 2015. Tabel I-O Indonesia 2010. BPS Jakarta. 
Badan Pusat Statistik, 2016. Tabel I-O Papua Barat 2015. BPS Manokwari.

Badan Pusat Statistik, 2017. Keadaan Angkatan Kerja Di Provinsi Papua Barat Agustus 2017, BPS Papua Barat. Manokwari.

Badan Pusat Statistik, 2017. Produk Domestik Regional Bruto Provinsi Papua Barat Menurut Lapangan Usaha 2013-2017. BPS Manokwari.

Badan Pusat Statistik, 2017. Provinsi Papua Barat Dalam Angka 2016. BPS Manokwari.

Bank Indonesia, 2014. Kajian Ekonomi dan Keuangan Regional Provinsi Papua Barat Triwulan IV 2014. Manokwari

Bank Indonesia, 2015. Kajian Ekonomi dan Keuangan Regional Provinsi Papua Barat Triwulan IV 2015. Manokwari

Bank Indonesia, 2016. Kajian Ekonomi dan Keuangan Regional Provinsi Papua Barat Triwulan IV 2016. Manokwari

Bank Indonesia, 2017. Kajian Ekonomi dan Keuangan Regional Provinsi Papua Barat Triwulan IV 2017. Manokwari

Departemen Keuangan RI., 2004. Keputusan Menteri Keuangan RI No. 248 / kmk. 06 Tahun 2003. Tentang Penerimaan Bagi Hasil Sumber Daya Alam.

Kanwil Ditjen Perbendaharaan Provinsi Papua Barat. 2016. Kajian Fiskal Regional Provinsi Papua Barat Tahun 2016. Manokwari

Kanwil Ditjen Perbendaharaan Provinsi Papua Barat. 2017. Kajian Fiskal Regional Provinsi Papua Barat Tahun 2017. Manokwari

Landau, D. 1986. Government and Economic Growth in the Less Developed Countries. An Empirical Study for 1960-1980. Economic Development and Cultural Change Vol. 35, No. 4 (October).
Lin, Steven A. (1994). Goverment Spending and Economic Growth. Applied Economic. 26:83-94

Mardiasmo., 2009, Akuntansi Sektor Publik, Yogyakarta: ANDI

Musgrave, R.A. (1959) The Theory of Public Finance. McGraw Hill, New York

Pemerintah Daerah Provinsi Papua Barat, 2013. Realisasi Anggaran Pendapatan dan Belanja Daerah Provinsi Papua Barat Tahun 2012.

Pemerintah Daerah Provinsi Papua Barat, 2014. Realisasi Anggaran Pendapatan dan Belanja Daerah Provinsi Papua Barat Tahun 2015.

Pemerintah Daerah Provinsi Papua Barat, 2015. Realisasi Anggaran Pendapatan dan Belanja Daerah Provinsi Papua Barat Tahun 2016.

Pemerintah Daerah Provinsi Papua Barat, 2016. Realisasi Anggaran Pendapatan dan Belanja Daerah Provinsi Papua Barat Tahun 2017.

Peraturan Daerah Provinsi Papua Barat Nomor 4 Tahun 2013 Tentang Rencana Tata Ruang Wilayah Provinsi Papua Barat Tahun 20132033.

Peraturan Daerah Provinsi Papua Barat Nomor 18 Tahun 2012 tentang Rencana Pembangunan Jangka Menengah Daerah (RPJMD) Provinsi Papua Barat Tahun 2012-2016.

Pressman, Steven. 2002. Lima Puluh Pemikir Ekonomi Dunia. Jakarta: PT. Raja Grafindo Persad.

Stiglitz, Joseph E., The General Theory of Tax Avoidance (March 1986). NBER Working Paper No.w1868. Available at SSRN: https://ssrn.com/abstract $=288467$. 